Ethiopian Journal of Environmental Studies \& Management 8(Suppl. 1): 835 - 845, 2015.

ISSN:1998-0507

doi: http://dx.doi.org/10.4314/ejesm.v8i1.11S

Submitted: June 30, 2015

Accepted: October 22, 2015

\title{
AN ASSESSMENT OF THE IMPACT OF VEHICULAR EMISSION ON PROXIMATE COMPOSITION OF ROADSIDE Amaranthus hybridus IN ZARIA METROPOLIS, KADUNA STATE, NIGERIA
}

\author{
EKWUMEMGBO, P.A., *OMONIYI, K.I. AND OKON, I.E.
}

Chemistry Department, Ahmadu Bello University, Zaria, Nigeria

\begin{abstract}
The work assesses the effect of vehicular emissions at traffic hotspots in Zaria metropolis, Nigeria on the proximate composition of roadside Amaranthus hybridus. The concentration of all the pollutants [particulate matter $(\mathrm{PM})$, nitrogen dioxide $\left(\mathrm{NO}_{2}\right)$, sulphur dioxide $\left(\mathrm{SO}_{2}\right)$, carbon monoxide (CO), carbon dioxide $\left(\mathrm{CO}_{2}\right)$ and hydrocarbons $\left.(\mathrm{CxHy})\right]$ were either below or within the Nigerian Ambient Air Quality Standard (NAAQS) limit of 0.05 ppm, with the exception of $\mathrm{CxHy}$ at the morning peak hours with mean value $0.055 \mathrm{ppm}$. The range of values determined for proximate composition of the Amaranthus hybridus were 29.41 $30.15 \%, 2.94-3.20 \%, 4.09-4.68 \%, 6.75-6.82 \%, 4.04-4.44 \%$ and $55.47-56.27 \%$ for the moisture, fat, ash, crude protein, crude fibre and carbohydrate contents respectively. There was no significant difference $(P<0.05)$ in the proximate compositions of the Amaranthus hybridus cultivated at the roadside (experimental sites) compared to the control. Therefore, vehicular emissions did not cause any negative impact on the proximate composition of roadside Amaranthus hybridus in Zaria metropolis.
\end{abstract}

Key Words: Amaranthus hybridus, Proximate Composition, Roadside Vehicular Emissions

\section{Introduction}

The plant Amaranthus hybridus, a nutritious and leafy vegetable is a member of the Amaranthaceae family. It has a variety of uses of which the common use is vegetable (Omosun et al., 2008). Apart from this, it is also used as herbal medicine since it has medicinal values for the treatment of intestinal bleeding, diarrhea and excessive menstruation (Foster and Duke, 1990).

The emission of pollutants by vehicles into the atmosphere as a result of traffic density emanating from high fleet growth, increased population, increased urbanization and economic improvement can cause serious damage to the environment (Akpan et al., 2014; Faboya,
1997; Magbagbeola, 2001; Iyoha, 2002; Akanni, 2010).

These pollutants affect animals and man and by extension crops cultivated on places exposed to this emission especially those close to road sides. The negative effects of vehicular emission on roadside crops have been illustrated by Naveed et al. (2010). Rejini and Janardhanan, (1989) illustrated that some pollutants like the photochemical oxidants (ozone and peroxyacetyl nitrate) which are formed by sunlight acting on products of fuel combustion particularly the nitrogen dioxide and hydrocarbons that come from vehicle exhaust are dangerous to plants as plant leaves are sensitive to them. Durrani et al., 2004 showed that excessive $\mathrm{NO}_{2}$ in

*Corresponding author: Omoniyi, K.I.

Email: israelflourish@yahoo.com 
the atmosphere damages leaves of plants, reduce photosynthetic activity and also causes chlorosis. Also, $\mathrm{SO}_{2}$ can inhibit or promote stomata closure depending on its concentration coupled with other pollutants in the environment (Viskarri et al., 2000).

The main products of the combustion of motor fuels are carbon dioxide and water but inefficiencies and high temperature inherent in engine operation encourages the production of many other pollutants of varying effects. The nutritional contents of Amaranthus hybridus could be affected by pollutants from vehicular emissions while at high concentrations, if cultivated close to road side.

The objective of this study therefore, is to investigate the impact of the pollutants from vehicular emission in Zaria metropolis on the proximate composition of Amaranthus hybridus cultivated on the roadside within Zaria metropolis at traffic hotspots.

\section{Materials and Method}

This study was conducted in Zaria metropolis located in Kaduna State, Nigeria. It was conducted over a period of six weeks between the 4th of March and the 14th of April, 2013. Four sampling points: REX junction $\left(11^{\circ} 6^{\prime} 25^{\prime \prime} \mathrm{N}\right.$, $7^{\circ} 43^{\prime} 26^{\prime \prime}$ E), PZ junction $\left(11^{\circ} 6^{\prime} 17^{\prime \prime} \mathrm{N}\right.$, $\left.7^{\circ} 43^{\prime} 13^{\prime \prime} \mathrm{E}\right)$, MTD junction $\left(11^{\circ} 7^{\prime} 26^{\prime \prime} \mathrm{N}\right.$, $7^{\circ} 42^{\prime} 48^{\prime \prime}$ E) and Kwangila Fly-Over $\left(11^{\circ} 8^{\prime} 35^{\prime \prime} \mathrm{N}, 7^{\circ} 42^{\prime} 73^{\prime \prime}\right.$ E) which are all located at traffic congested areas of Zaria, served as the experimental sites. The fifth site which was 250 metres away from the road was used as the control site; this site is a farmland in Palladan, Zaria metropolis $\left(11^{\circ} 8^{\prime} 51^{\prime \prime} \mathrm{N}, 7^{\circ} 41^{\prime} 29^{\prime \prime} \mathrm{E}\right)$, this has no traffic and no vehicular emission. The experimental sites were chosen based on volume of traffic and the possibility of having crops cultivated at only 5 metres away from road edge considering the safety and security of the crop under study. Sampling for Air Quality Parameters

The climatic elements sampled were the ambient temperature $\left({ }^{\circ} \mathrm{C}\right)$, relative humidity $(\%)$, and wind velocity $\left(\mathrm{ms}^{-1}\right)$. Air quality parameters sampled were particulate matter (PM), nitrogen dioxide $\left(\mathrm{NO}_{2}\right)$, sulphur dioxide $\left(\mathrm{SO}_{2}\right)$, carbon monoxide $(\mathrm{CO})$, carbon dioxide $\left(\mathrm{CO}_{2}\right)$ and hydrocarbons $(\mathrm{CxHy})$. These parameters were measured using the Growncon Gasman auto sampler (CE89/336/EEC model) which is an automatic instrument that measures $\mathrm{CO}, \mathrm{NO}_{2}, \mathrm{SO}_{2}$ and $\mathrm{CxHy}$. Particulate matter was measured using the Hazdust (HD 1000 model) emission analyser while $\mathrm{CO}_{2}$ was measured using the GE 2028 model gas analyser. Temperature and humidity were measured using the TES 360 model humidity/temperature metre, while Kestrel 400 weather tracker was used to measure the wind speed. Global Positioning System (GPS) was used in taking coordinates of the sampling locations. Data collection was carried out in triplicate for each of the parameters. Collection of data from the sampling points was carried out thrice a day for three working days (Monday, Wednesday and Friday) within the study time frame (4th of March to 14th of April, 2013). The three time periods were: 7.00 am -10.00 am morning peak hours; 10.00 am -1.00 pm off-peak hours; 4.00 pm $7.00 \mathrm{pm}$ evening peak hours. 


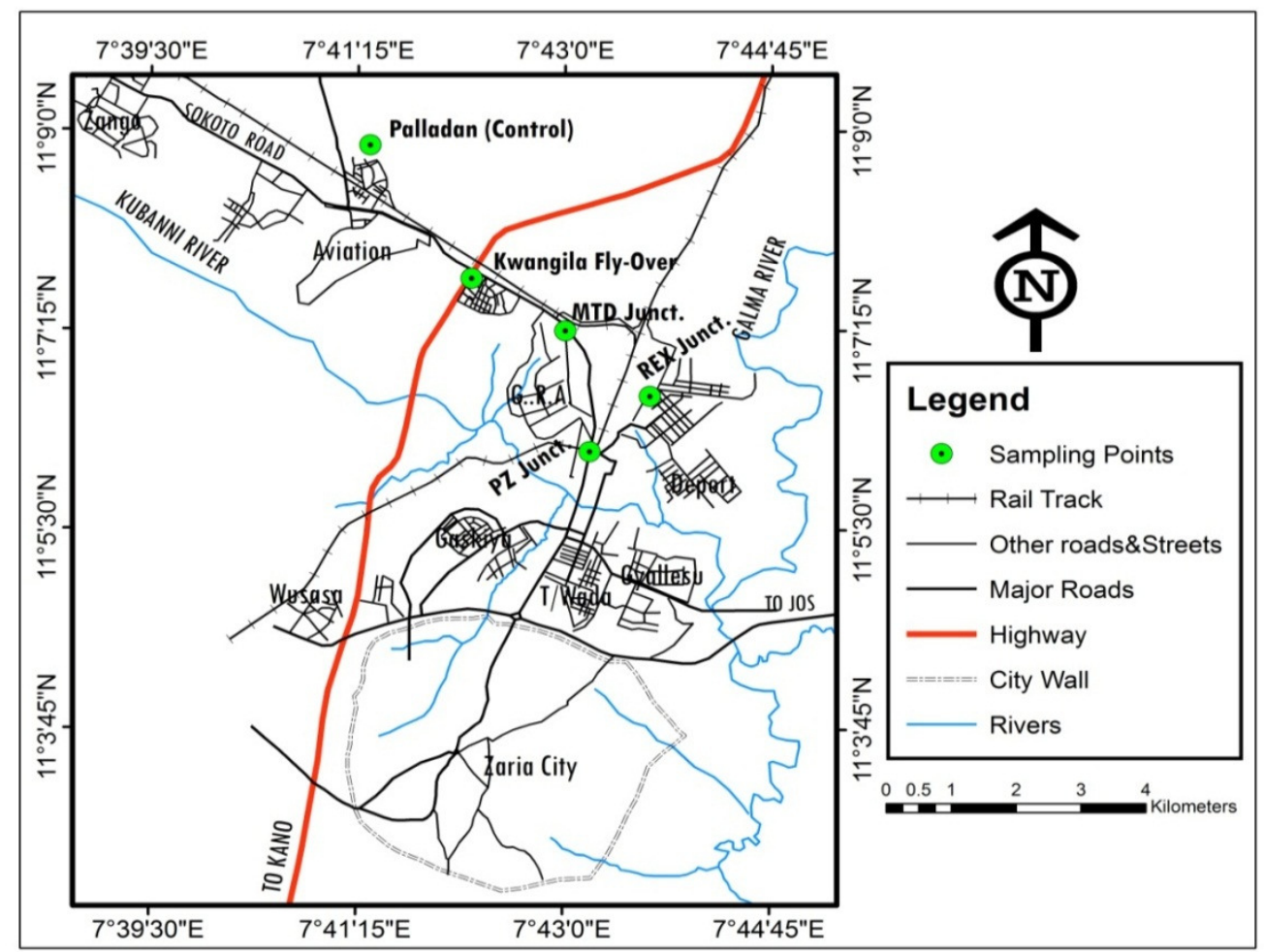

Figure 1: Map of Zaria metropolis showing sampled areas

\section{Cultivation of Amaranthus hybridus}

Viable seeds of Amaranthus hybridus obtained from the Institute of Agricultural Research, Ahmadu Bello University $(A B U)$, Zaria, Nigeria were cultivated in pots using good soil of uniform composition collected from the Soil Science Department of ABU. The pots were kept $5 \mathrm{~m}$ away from the road edge at the traffic hot spots. Three planting pots each containing about twenty plant stands were kept at each of the five sampling points. The control samples were cultivated on the same soil, while the pots were kept at a distance $250 \mathrm{~m}$ away from the road.

\section{Collection of Amaranthus hybridus Samples and Treatment}

Three crop stands were randomly collected from each of the planting pots located at each of the sites during each sampling $(n=45)$. The sample collection was carried out four times bringing the total number of samples 180 at the end of six weeks of planting the seeds. Sampling was carried out on a weekly basis from the third week of growth through to the sixth. The samples collected were then labeled for identification.

The fresh vegetable samples were washed with tap water once and then rinsed with de-ionized water several times. The samples were then air dried to remove residual moisture at room temperature, before they were sun-dried for three days at $32-34^{\circ} \mathrm{C}$, and relative humidity $(\mathrm{RH})$, $40-45 \%$ on a clean paper spread on concrete floor, with regular turning to avert microbial growth (Akubugwo et al., 2007). The samples were then ground into fine powder using an agate pestle and mortar, and sieved through a $2.0 \mathrm{~mm}$ sieve to obtain a dried powdered sample that was used for all the analyses.

\section{Proximate Analysis of Amaranthus hybridus}

Moisture content, fat content, ash content and crude fibre were determined in 
accordance with the official methods of the Association of Analytical Chemists (AOAC, 1980). Nitrogen was determined by the Kjeldahl method and the percentage of nitrogen was converted to crude protein by multiplying by 6.25 . Carbohydrate content was determined by the difference.

\section{Statistical Analyses}

All analyses were done in triplicates; and the data analyzed by calculating the mean and standard deviation. Student t-test statistical tool was used to test the impact of vehicular emissions on the proximate composition by comparing the mean proximate composition in the Amaranthus hybridus cultivated at each experimental site to the control counterpart at $\mathrm{P}<0.05$.

\section{Result and Discussion}

The results for air quality parameters are presented in Figure 2 - 7; proximate composition analysis is presented in Figure 8 , while statistical analysis is presented in Table 1.

\section{Wind Speed}

The average wind speed at all experimental sites varied between $3.40 \pm$ $0.36-3.73 \pm 0.35 \mathrm{~ms}^{-1}$ during the morning peak traffic period; $3.53 \pm 0.50-3.77 \pm$ $0.25 \mathrm{~ms}^{-1}$ during the evening peak traffic period and $3.53 \pm 0.05-3.77 \pm 0.25 \mathrm{~ms}^{-1}$ during the off-peak traffic period. These are higher than the range of $1.24 \pm 0.27-$ $1.21 \pm 0.23 \mathrm{~ms}^{-1}$ reported for Port Harcourt city by Utang and Peterside (2011).

\section{Air Temperature}

The average temperature at all the sites considered ranged from $28.00 \pm 1.00-$ $29.20 \pm 0.20^{\circ} \mathrm{C}$ during the morning peak traffic period; $33.00 \pm 0.50-34.00 \pm$ $1.00^{\circ} \mathrm{C}$ during the evening peak traffic period and $33.00 \pm 2.00-35.5 \pm 0.20^{\circ} \mathrm{C}$ during the off-peak traffic period. These ranges of temperature were slightly different from the range of $31.9 \pm 0.39-$ $35.58 \pm 2.29^{\circ} \mathrm{C}$ reported by Utang and Peterside (2011).

\section{Humidity}

The average humidity were in the range of $71.00 \pm 2.00-74 \pm 2.00 \%$ during morning peak traffic period; $45.2 \pm 0.50-$ $46.3 \pm 0.80 \%$ during evening peak traffic period and $45.2 \pm 0.4-46.3 \pm 0.70 \%$ during off-peak traffic period. The average humidity values were low during off-peak and evening peak as a result of increase in temperature.

\section{Air Quality Parameters \\ Particulate matter (PM)}

The concentrations of PM during evening peak were higher than those of morning peak except at Kwanglila FlyOver and Rex Junction where the morning peak and the evening peak had the same concentration value of $213.000 \mu \mathrm{g} / \mathrm{m}^{3}$ and $192 \mu \mathrm{g} / \mathrm{m}^{3}$ respectively, this could be as a result of residual accumulation from morning and afternoon (Figure 2). PM concentration was higher at Kwangila FlyOver than every other site, this could be as a result of the high traffic density of heavy duty vehicles $(90.33 \mathrm{v} / \mathrm{h})$ at this point during peak traffic periods since heavy duty vehicles emit more PM than light vehicles (Sawyer, 2010). The concentrations of PM at all locations were below the Nigerian Ambient Air Quality Standard (NAAQS) limit of $250 \mu \mathrm{g} / \mathrm{m}^{2}$. 


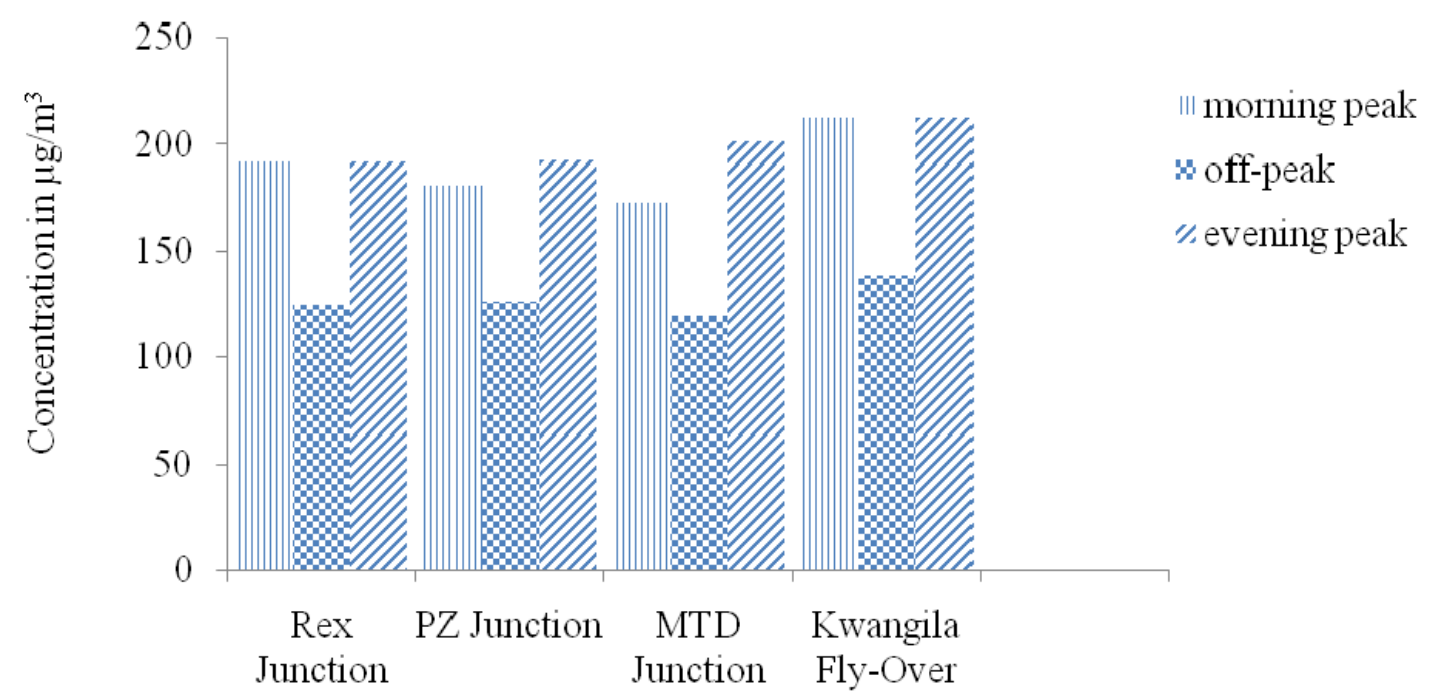

Figure 2: Concentration of PM in the Air of Zaria Metropolis

\section{Nitrogen dioxide $\left(\mathrm{NO}_{2}\right)$}

$\mathrm{NO}_{2}$ concentrations were also higher during evening peak than morning peak and this could also be as a result of the residual accumulation from morning and afternoon. The highest concentration of $0.045 \pm 0.002 \mathrm{ppm}$ for $\mathrm{NO}_{2}$ was found at Kwangila Fly-Over during evening peak traffic period (Figure 3). This could also be attributed to the high number of heavy duty vehicles at Kwangila Fly-Over which naturally will emit more $\mathrm{NO}_{2}$ than light vehicles (Tsai et al. 2006; Sawyer, 2010). The concentrations of $\mathrm{NO}_{2}$ at all locations were within the NAAQS limit range of $0.04-0.06 \mathrm{ppm}$ for $\mathrm{NO}_{2}$ and the $\mathrm{WHO}$ guideline limit of $0.17 \mathrm{ppm} \quad \mathrm{NO}_{2}$. However, the values obtained in this study were lower than those reported by Okunola et al., (2012) for Kano metropolis, with range $0.11-0.43 \mathrm{ppm}$ and mean $\mathrm{NO}_{2}$ of $0.2 \pm 0.1 \mathrm{ppm}$ for two local government areas in Ibadan, Nigeria reported by John et al. (2013). This could be accounted for by the fact that the population density and traffic congestion of Zaria is evidently far less than these two cities in Nigeria.

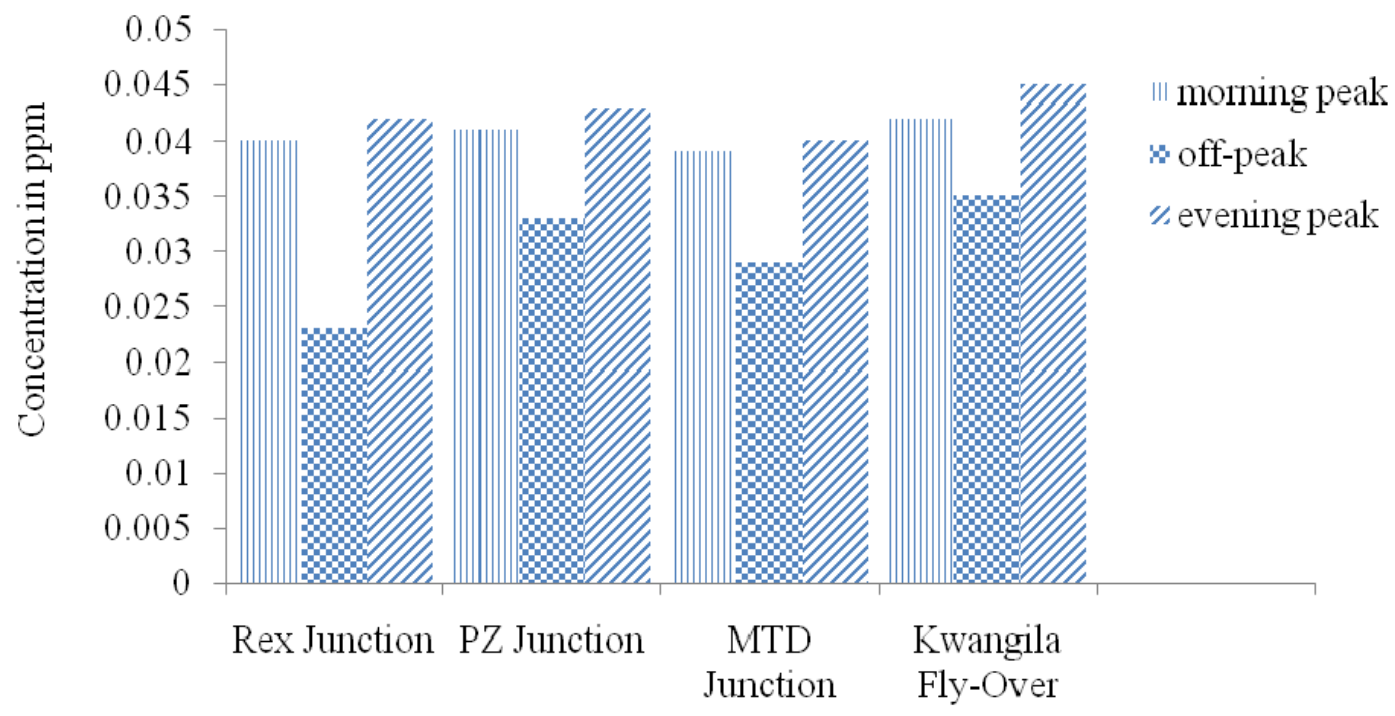

Figure 3: Concentration of $\mathrm{NO}_{2}$ in the Air of Zaria Metropolis 


\section{Sulphur dioxide $\left(\mathrm{SO}_{2}\right)$}

Unlike the other pollutants, the concentrations of $\mathrm{SO}_{2}$ obtained for the air during the evening peak traffic period were not higher than the concentrations obtained during the morning peak traffic period. The concentration range $0.040-0.042$ ppm $\mathrm{SO}_{2}$ was obtained for the experimental sites during the peak traffic periods (Figure 4); the values of this study is lower than the mean $\mathrm{SO}_{2}$ level of $1.0 \pm$
$0.7 \mathrm{ppm}$ for two local government areas in Ibadan, Nigeria (John et al., 2013), and the range $0.00-0.19 \mathrm{ppm}$ for Kano metropolis, Nigeria (Okunola et al., 2012); likewise less than the range $0.04-0.15$ ppm reported by Abam and Unachukwu (2009) for the air of a South-east Nigerian town. The $\mathrm{SO}_{2}$ in the air of Zaria is within the NAAQS limit range of $0.01-0.1 \mathrm{ppm}$ for $\mathrm{SO}_{2}$ and less than the $\mathrm{WHO}$ guideline limit of $0.17 \mathrm{ppm}$.

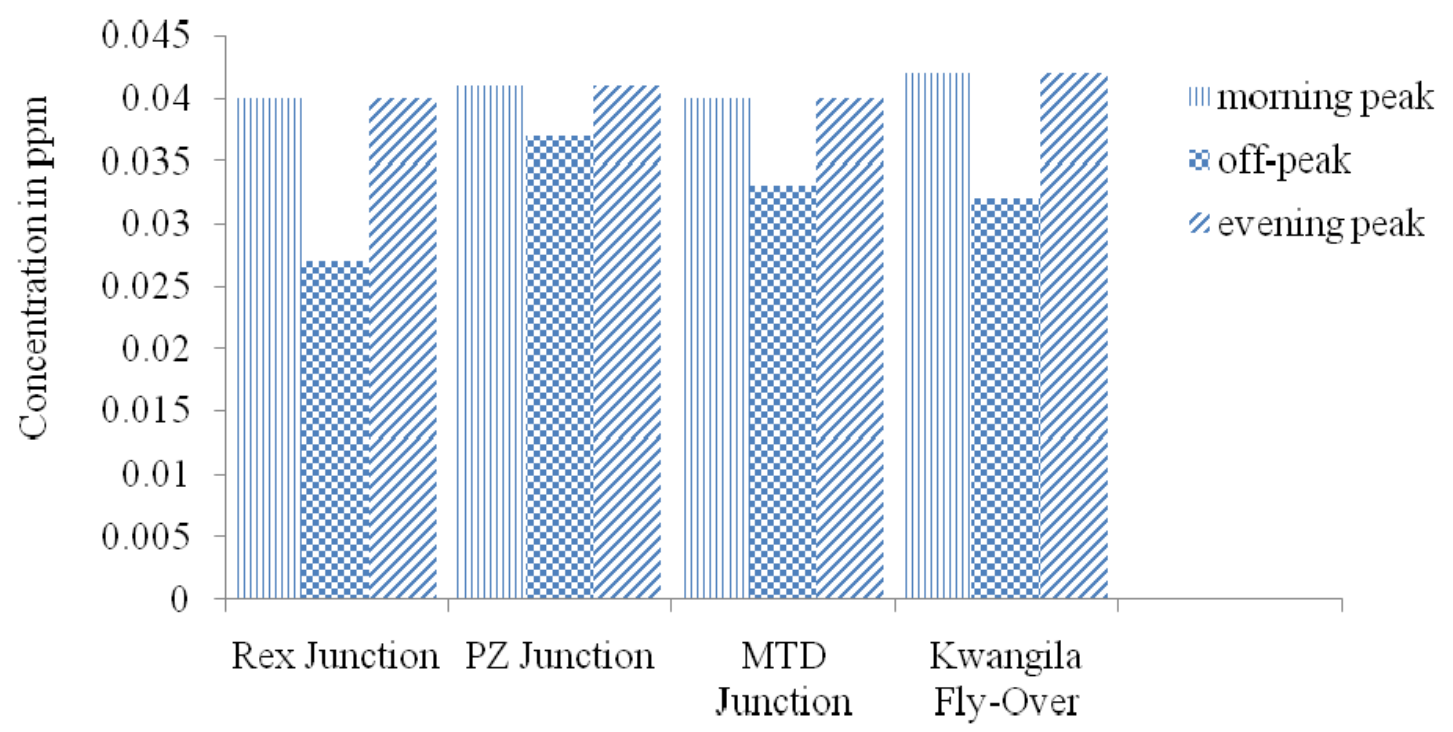

Figure 4: Concentration of $\mathrm{SO}_{2}$ in the Air of Zaria Metropolis

\section{Carbon monoxide ( $\mathrm{CO})$}

As depicted in Figure 5, the concentrations of $\mathrm{CO}$ during the evening peak traffic period were higher than those obtained during the morning peak traffic period at all locations; this could also be as a result of residual accumulation from the morning and afternoon. The concentration range $11.50-18.60 \mathrm{ppm}$ was obtained for $\mathrm{CO}$ at the traffic peak periods; this is within the NAAQS limit range of $10-20$ ppm, though far higher than the 1.25 $4.00 \mathrm{ppm}$ reported for Tse-Kucha community of Benue State, Nigeria (Abdulkarim et al., 2007) and the range 4.25 - $8.93 \mathrm{ppm}$ for the air of Kano metropolis, Nigeria (Okunola et al., 2012). On the other hand, the range $11.50-18.60$ ppm obtained for the air at Zaria, Nigeria was lower than the mean $\mathrm{CO}$ of $38.6 \pm$ $22.2 \mathrm{ppm}$ reported for two local government areas in Ibadan, Nigeria (John et al., 2013). It is inferred that the $\mathrm{CO}$ emitted from the vehicular traffic in Zaria exceeds the WHO guideline limit of 10 ppm. 


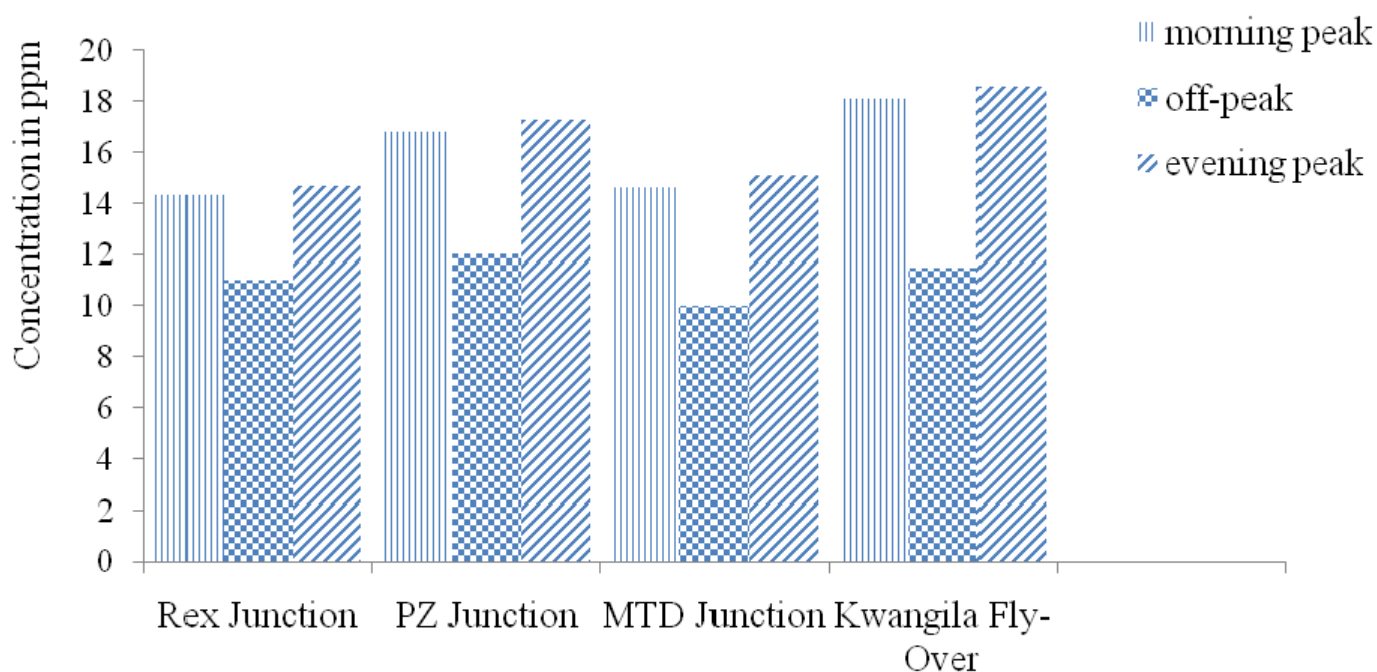

Figure 5: Concentration of $\mathrm{CO}$ in the Air of Zaria Metropolis

\section{Carbon dioxide $\left(\mathrm{CO}_{2}\right)$}

As presented in Figure 6, $\mathrm{CO}_{2}$ showed the same trend of higher concentration during the evening peak traffic period than the morning peak period with very high concentration when compared to $\mathrm{CO}$ mean $345 \pm 22.2 \mathrm{ppm}$; this could be as a result of the fact that $\mathrm{CO}$ is rapidly oxidised to $\mathrm{CO}_{2}$ as it is emitted by vehicles into the atmosphere (Abdulkarim et al., 2007; Wallington et al., 2008). The concentrations of $\mathrm{CO}_{2}$ at all locations were below the NAAQS limit of $600 \mathrm{ppm}$.

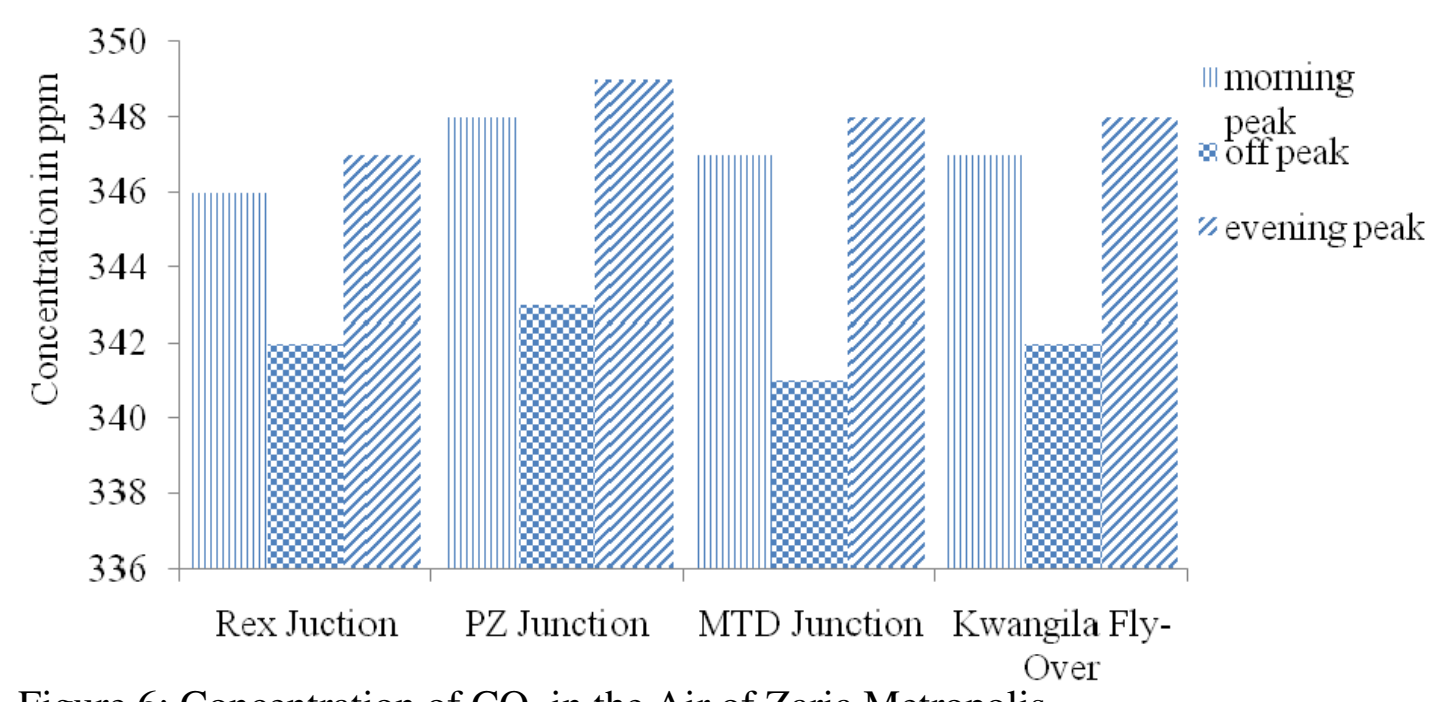

Figure 6: Concentration of $\mathrm{CO}_{2}$ in the Air of Zaria Metropolis

\section{Hydrocarbons (CxHy)}

Following from Figure 7, CxHy concentrations in the air during the evening peak traffic period were not higher than those obtained during morning peak traffic period as in the case of $\mathrm{SO}_{2}$ but the concentrations were all higher than the NAAQS limit of $0.05 \mathrm{ppm}$ for hydrocarbons, but the concentrations during the off-peak traffic period were below the $0.05 \mathrm{ppm}$ NAAQS limit at all locations. 


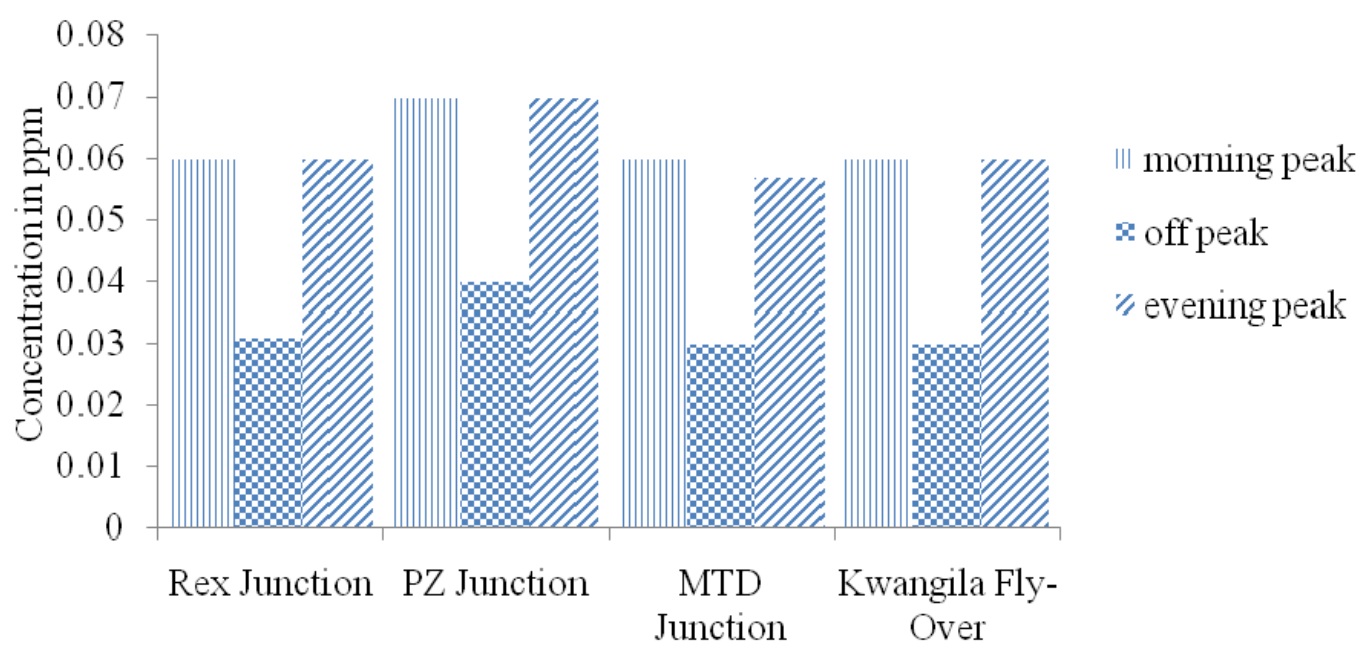

Figure 7: Concentration of $\mathrm{CxHy}$ in the Air of Zaria Metropolis

\section{Proximate Composition}

From the results presented in Figure 8, the values of proximate composition of some nutrients in the Amaranthus hybridus cultivated at the experimental sites exposed to vehicular emissions were generally higher than the ones cultivated at the control site. The fat content values 3.19 $\pm 0.11 \%$ and $3.20 \pm 0.11 \%$ at Rex Junction and PZ Junction respectively were higher than the $3.14 \pm 0.20 \%$ at the control; likewise the values for ash content being $4.10 \pm 0.37 \%, 4.38 \pm 0.18 \%, 4.54 \pm$ $0.45 \%, 4.68 \pm 0.35 \%$ at Rex Junction, PZ Junction, MTD Junction and Kwangila Fly-Over respectively were higher than the $4.09 \pm 0.17 \%$ at the control. Crude protein content of $6.82 \pm 0.63 \%$ and $6.80 \pm 0.06 \%$ at Rex Junction and Kwangila Fly-Over respectively were higher than the $6.77 \pm$ $0.65 \%$ at the control.

The study also indicated that carbohydrate content values of $56.09 \pm$ $3.81 \%$ and $56.27 \pm 3.46 \%$ at Rex Junction and MTD Junction respectively were higher than the mean value of $55.78 \pm$ $4.08 \%$ at the control. However, the levels of fat, carbohydrate, crude protein and ash in the experimental vegetable did not differ significantly $(\mathrm{P}<0.05)$ from the levels in the control samples.

The result therefore implies that vehicular emissions in Zaria metropolis did not reach the level that can cause a remarkable negative impact on the proximate composition of Amaranthus hybridus cultivated on the road side, although the air pollutants at all the experimental sites were really higher than the control values.

The range $4.09-4.68 \%, 2.94-3.20 \%$, $4.04-4.44 \%$ and $6.75-6.82 \%$ for ash content, fat content, crude fibre and crude protein for the crop from all the sites were respectively lower than the $13.80 \%, 4.65$ $\%, 8.61 \%$ and $17.92 \%$ reported by Akubugwo et al., (2007) for Amaranthus hybridus leaves from Afikpo, Nigeria. The range 55.47 - $55.76 \%$ for carbohydrate content of the crops from all the sites were higher than the $52.18 \%$ reported by Akubugwo et al. (2007). And the range $4.09-4.68 \%, 2.94-3.20 \%, 4.04-4.44 \%$ and $6.75-6.82 \%$ for ash content, fat content, crude fibre and crude protein were respectively lower than the $15.55 \%$, $14.02 \%, 8.05 \%$ and $49.09 \%$ reported by Asaolu et al. (2012) for some common Nigerian leafy vegetables. The range 29.41 $-30.15 \%$ and $55.47-55.76 \%$ for moisture content and carbohydrate respectively obtained for the Amaranthus hybridus used for this study were higher than the $10.0 \%$ and $3.36 \%$ reported by Asaolu et al. (2012). 


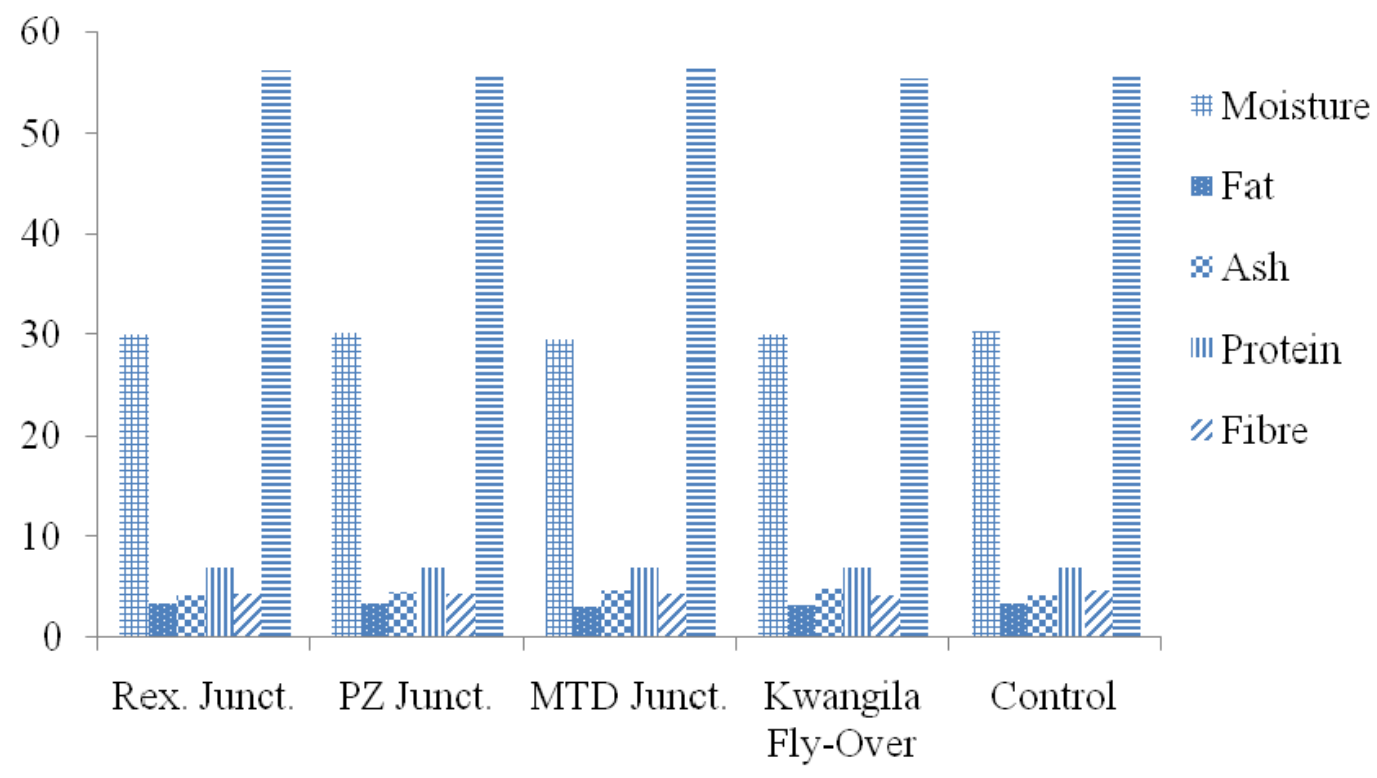

Figure 8: Proximate Composition of Amaranthus hybridus from Zaria Metroplois

\section{Impact of Vehicular Emissions on} Proximate Composition

The proximate composition of the Amaranthus hybridus cultivated at the experimental and at the control site were compared using $\mathrm{t}-$ test (Table 1). The moisture, ash, fat, crude protein, carbohydrate and crude fibre contents of the vegetable were not significantly different in the two groups; since the $\mathrm{t}$ - calculated were all lower than the t-critical (3.18). This shows that vehicular emissions did not have negative impact on the proximate composition of the road side Amaranthus hybridus in Zaria metropolis. The lower value of ash content, fat content, crude fibre and crude protein compared to Akubugwo et al. (2007) and Asaolu (2012) could be attributed to other environmental factors like soil type among others.

Table 1: T- Test values for Comparing Mean Proximate Composition at Experimental Sites to that at Control at 0.05 Significance Level (two-tail)

\begin{tabular}{|c|c|c|c|c|c|c|c|}
\hline Sites & \multicolumn{6}{|c|}{ t-calculated for Proximate Composition comparism } & \multirow[t]{2}{*}{ t-critical } \\
\hline & Moisture & Fat & Ash & Protein & Fibre & Carbohydrate & \\
\hline Rex Junction & 0.54 & -0.59 & -0.06 & -2.03 & 0.92 & -0.44 & 3.18 \\
\hline PZ Junction & 0.23 & 1.08 & -1.86 & 0.09 & 2.25 & 0.05 & 3.18 \\
\hline MTD Junction & 1.58 & 1.78 & -1.48 & 0.29 & 1.13 & -0.84 & 3.18 \\
\hline $\begin{array}{l}\text { Kwangila Fly- } \\
\text { Over }\end{array}$ & 2.67 & 0.29 & -2.81 & -1.29 & 1.5 & 1.79 & 3.18 \\
\hline
\end{tabular}

\section{Conclusion}

The concentration of all the pollutants $\left(\mathrm{PM}, \mathrm{NO}_{2} \mathrm{SO}_{2}, \mathrm{CO} \mathrm{CO}_{2}\right.$ and $\mathrm{CxHy}$ ) emanating from vehicular emissions in the air of Zaria metropolis were either below or within the NAAQS limit with the exception of only $\mathrm{CxHy}$, meaning that vehicular emissions have not reach the level that can really cause negative impact on the air quality of Zaria metropolis. Vehicular emissions did not cause negative impact on the proximate composition of roadside Amaranthus hybridus since there was no significant difference in the proximate compositions of the ones cultivated at the roadside compared to the control. The study therefore indicates that the consumption of Amaranthus hybridus 
planted on road side soils proximal to the anticipated influence of vehicular emissions in some selected areas of Zaria metropolis, Nigeria does not constitute health concern; as the proximate compositions of the crop were not negatively impacted. Also the gaseous pollutants that normally raise grave health concern from vehicular emissions were all within the threshold levels. Notwithstanding, environmentalists do continually canvass for options such as tree planting, reduction in the overpopulation of cities, proper conditions of automobiles, environmentally friendly alternatives to fuels and a plethora of other options for the realization of the dream of a clean environment.

\section{References}

Abam, F.I. and Unachukwu, G.O. (2009). Vehicular emission and air quality standards in nigeria. European Journal of Scientific Research, 34(4): 550- 560.

Abdulkarim, B.I. and Chiroma, T.M. (2007). Assessement of $\mathrm{CO}, \mathrm{CO}_{2}$ and suspended particulate matter emissions, Leonardo Electronic Journal of Practice and Technology, 6 (11): $109-116$.

Akanni, C.O. (2010). Spatial and seasonal analysis of traffic-related pollutant concentrations in Lagos metropolis, Nigeria. African Journal of Agricultural Research, 5(11): 1264 1272.

Akpan, P.E., Usip, E.E. and Jeremiah. U.O.(2014). Impact of traffic volumes on air quality in Uyo urban, Akwa Ibom State, Nigeria. Journal of Environment and Earth Science, 49(2): 189 - 201

Akubugwo, I. E., Obasi, N. A., Chinyere, E. C. and Ugboku, A. E. (2007). Nutritional and chemical value of Amaranthus hybridus leaves from
Afikpo, Nigeria. Africa Journal of Biotechnology, 6(24): 2833-2839.

AOAC (1980). Official methods of analysis $\left(13^{\text {th }}\right.$ edition), Association of Official Analytical Chemists, Washington DC.

Asaolu, S.S., Adefemi, O.S., Oyakilome, I.G., Ajibulu, K.E. and Asaolu, M.F. (2012). Proximate and mineral composition of Nigerian leafy vegetables. Journal of Food Research, 1(3): $214-218$.

Durrani, G.F., Hassan, M., Balock, M.K. and Hameed, G. (2004). Effect of traffic pollution on plant photosynthesis. Journal of Chemical Society of Pakistan, 26 (2): 176-179.

Faboya, O. (1997). Industrial pollution and waste management. In: Osuntokun, A. (ed.), Dimensions of Environmental Problems in Nigeria, Ibadan Davidson Press, Nigeria, pp. $26-35$.

Foster, S. and Duke J.A. (1990). A field guide to medicinal plants of Eastern and Central North America. Houhton Miffin Co. U.S.A.

Iyoha, M.A. (2002). The environmental effects of oil industry activities on the Nigerian Economy: a theoretical analysis. In: Orubu, C., Ogisi, D. and Okoh, R. (eds.), The Petroleum Industry, the Economy and the Niger Delta Environment. Proceedings of National Conference on the Nigerian Petroleum Industry and the Niger Delta Environment.

John, O., Olamijulo, E., Godson, R. and Ana, E. (2013). Air quality in relation to vehicular traffic-related gaseous emissions in two selected Local Government Areas in South-Western Nigeria. International Journal of Environmental Monitoring and Analysis, 1(4): 121-127.

Magbagbeola, N.O. (2001). The use of economic instruments for industrial 
pollution abatement in Nigeria: Application to the Lagos Lagoon. In: Nigeria Economic Society, Natural Resources Use, University of Ibadan, Ibadan, Nigeria. pp. 535-556.

Naveed, N.H., Batool, A.I., Rehman, U.F. and Hameed, U. (2010). Leaves of roadside plants as bioindicator of traffic related lead pollution during different seasons in Sarghodha, Parkistan. African Journal of Environmental Science and Technology, 4(11): 770-774.

Nigerian Ambient Air Quality Standards. Federal Environmental Protection Agency (1991). Guidelines and Standards for Environmental Protection Control in Nigeria.

Okunola, O.J., Uzairu, A., Gimba C.E. and Ndukwe, G.I. (2012). Assessment of gaseous pollutants along high traffic roads in Kano, Nigeria. International Journal of Environment and Sustainability, 1(1): 7-11.

Omosun, G., Markson, A. A. and Mbanaso, O. (2008). Growth and anatomy of Amaranthus hybridus as affected by different crude oil concentrations. American-Eurasian Journal of Scientific Research, 3(1): $70-74$

Rejini, M.B.J., Janardhanan, K. (1989). Effect of heavy metals on seed germination and early seedling growth of groundnut, sunflower and ginger. Geobios, 16: $164-170$.

Sawyer, R.F. (2010). Vehicle emissions, progress and challenges. Journal of Exposure Science and Environmental Epidemiology, Issue 2010: 487 - 488.

Tsai, W.Y., Chan, L.Y., Blake, D.R. and Chu, K.W. (2006). Vehicle fuel composition and atmospheric emission in South China: Hong Kong, Macau, Ghanzhou and Zhuhai. Atmospheric Chemistry And Physical Discussions, 6: 3687 - 3706.

Utang, P.B. and Peterside, K.S. (2011). Spatio-temporal variation in urban vehicular emission in Port Harcourt City, Nigeria. Ethiopean Journal of Environmental Studies and Management, 4(2): 38-51.

Viskarri, E.L., Kossi, S. and Holoppainen, J.K. (2000). Norway spruce and spruce shoot aphid as indicator of traffic pollution. Environmental Pollution, 107(3): 305-314.

Wallington, T.J., Sullivan, J.L. and Hurly, M.D. (2008). Emission of $\mathrm{CO}_{2}, \mathrm{CO}$, $\mathrm{NO}_{\mathrm{X}}, \mathrm{HC}, \mathrm{PM}, \mathrm{HFC}-134 \mathrm{a}, \mathrm{N}_{2} \mathrm{O}$ and $\mathrm{CH}_{4}$ from the global light duty vehicle fleet. Meteorologische Zeitschrist, 17(2): 109 - 116. 